\title{
In the Shadow of the Transit Spectacle
}

DOI 10.17234/9789531756525.8

Marijana Hameršak

Institute of Ethnology and Folklore Research

Šubićeva 42, 10000 Zagreb, Croatia

marham@ief.hr

Iva Pleše

Institute of Ethnology and Folklore Research

Šubićeva 42, 10000 Zagreb, Croatia

piva@ief.hr

In the shadow of a specific form of border spectacle (De Genova 2002) and the spectacle of statistics (Stierl et al. 2016), i.e. in the shadow of the spectacle of the mass transit of refugees on their way to Western Europe in the autumn and winter of 2015/2016, the so-called profiling and detention of migrants took place. Mostly invisible to the general public, this profiling led to the forced mass movement of refugees in the opposite direction and/or their explicit detention i.e. confinement. By relying on different types of sources, ranging from public reports to our own field observations, this article deals with detentions in the Croatian part of the Balkan corridor. According to the argument offered in this article, detention can be seen as an integral part of the corridor itself and can be traced from the beginning of its establishment. Furthermore, the article presents a basic outline of what was happening in the Slavonski Brod camp after the closure of the borders on the night of March $8^{\text {th }}$ to the $9^{\text {th }}, 2016$. It proposes a possible framework for understanding the imprisonment of hundreds of people in the camp from the perspectives of the specific "productiveness" of the camp and modes of resistance towards it.

Keywords: Balkan corridor, Slavonski Brod refugee camp, migrant detention, control and resistance

$\longrightarrow$ he so-called Balkan route, or "informal know-how" (Walters 2015a: 9) of clandestine movement shared amongst migrants to Western Europe, has been known about for a long time by experts in both national and supranational security bodies and services (cf. e.g. Frontex 2011; Frontex 2014), a variety of humanitarian and other agencies, as well as researchers in the field of migration (cf. Hassan and Biörklund 2016; Hess 2012; Tsianos and Karakayali 2010; Valenta et al. 2015). In 2015, this line of clandestine movement, which in some circles was previously well-known but almost completely invisible to the general public, transformed into a visible and mass movement across European soil, with border guards 
"enforcing an orderly passage of irregular flows, issuing various registration papers" (Frontex 2016: 15), as described even in Frontex publications with the characteristic naturalizing (flow) and technocratic (irregular) discourses (cf. Hart 2011: 572). As Bernd Kasparek summarizes, at this point, the path across the Balkans "entered into the European spotlight, and indeed onto the screen of the global public" (2016: 2). The route transformed into "a highly efficient infrastructure of transit" that had been established "across the Balkans, reaching from the ports of Piraeus and Thessaloniki to several regional distribution centres in Germany". It was "no longer just a route, but rather a corridor, i.e., a narrow and highly organised mechanism to channel and facilitate the movement of people that only states seem capable of providing" (Kasparek 2016: 6; cf. Beznec et al. 2016: 4; Lunaček Brumen and Meh 2016). The rules of this corridor and its pathways were established by formal and informal agreements between the police forces, ministries etc. and facilitated by governmental, humanitarian and other institutions and agencies.

At that point in time it seemed that the year of 2015 would be "a historic and monumental year of migration for Europe precisely because disobedient mass mobilities have disrupted the European regime of border control" (Stierl et al. 2016: 23). Today, it is obvious that the disruption was not only short-term, but for some people also illusionary since, for example, one of the cornerstones of that regime, the Dublin Regulation, ${ }^{1}$ was only allegedly suspended. As we know from first hand and published overviews (cf. Asylum 2017), deportations from Austria and other EU countries to Croatia already started in February 2016 and are still ongoing.

Building on the well-known concept of "border spectacle" (De Genova 2002), the visibility that the movement got in that period can be described as transit spectacle. This transit spectacle in the Croatian context consisted of countless images of crowded border crossings, nearby meadows, trains, buses and sorting centres or camps predominantly in Croatia, and sometimes in the border regions with Slovenia and Serbia, as well as the constant, literally real-time, spectacular presentation of the number of arrivals and exits. This spectacle of statistics (Stierl et al. 2016) is also echoed in summaries of the events such as the following:

"Between September 16, 2015 and March 5, 2016, a total of 658,068 migrants $[\ldots]$ entered the territory of Croatia. On average, there were approximately 5,500 daily arrivals, with a peak of 11,000 on September 17. [...] Throughout January 2016, the average number of migrants entering Croatia varied between 500 and 2,000, with some days reaching 3,000." (Šelo Šabić and Borić 2016: 11)

At: http://eur-lex.europa.eu/legal-content/en/TXT/?uri=celex\%3A32013R0604 (last access 8 March 2017). 
Although extremely visible and present in Croatian news and social networks, especially in the first months, the movement of migrants in the corridor across Croatia was in fact almost invisible concerning all aspects other than those mentioned above, i.e. large numbers and mass scenes. Reflecting contemporary European immigration policies (cf. e.g. De Genova et al. 2015; Fassin 2005; New Keywords 2016), this transit spectacle emphasized the humanitarian aspect and care for the suffering of an anonymous mass of people, while on the other hand insisting on organized, effective and secure migrant crossing through Croatia (cf. e.g. Grubiša 2017; Hameršak and Pleše 2017a, 2017b; Petrović 2016, 2017; Škokić and Jambrešić Kirin 2017). ${ }^{2}$

Concerning the fact that the public image of migrant transit was extremely limited and founded on the ideas of efficient and secure transit with a touch of traditional hospitality culture, other aspects such as dehumanization and detention as preconditions for, as well as integral parts of, this indeed efficient transit were not discussed. They were referred to in only a few reports by some NGOs and independent activists and mostly ignored by the media and, consequently, by the general public.

In comparison to the situation, for example, in Serbia or Macedonia where migrants followed the path of the corridor (cf. Beznec et al. 2016; Kasparek 2016: 6), in Croatia and from there onwards (cf. Ladić and Vučko 2016: 21-22; Kogovšek Šalamon 2016: 44-47), they were in the corridor's power, i.e. forced to follow the corridor and remain detained within it. Generally, one could not exit the corridor on one's own accord to satisfy individual needs such as to slow down and rest or to speed up one's journey, to stay the night in a hotel room instead of a tent or on a floor as it was in Dobova (Slovenia), to mention only a few of the situations we encountered in the camps in Dobova and Slavonski Brod. ${ }^{3}$ For example, a man who asked to return to Turkey for the funeral of his close relative was not allowed to exit

2 The insights and argumentation presented in this article are partly based on our article "Zarobljeni u kretanju. O hrvatskoj dionici balkanskog koridora" [Confined in Movement. About the Croatian Section of the Balkan Corridor] (Hameršak and Pleše 2017b).

3 In order to denaturalise the term detention and to stress "the extent to which it has been reserved as a category for naming precisely those varieties of confinement that are intended to be emphatically distinguished from the more customarily juridical coordinates of penal imprisonment for criminal offenses" (De Genova 2016: 5), in this article we interchangeably use the terms detention, imprisonment, incarceration, confinement, etc. In this way, we want to distance ourselves from diminishing the facts that, with detention, the condition of so-called irregular migrants "culminates in summary (and sometimes indefinite) incarceration on the basis of little more than their sheer existential predicament as 'undesirable' non-citizens, usually with little or no recourse to any form of legal remedy or appeal, and frequently no semblance to any due process of law whatsoever. Migrants subjected to detention, very commonly, are literally 'guilty' of nothing other than their 'unauthorized' (illegalized) status, penalized simply for being who and what they are, and not at all for any act of wrong-doing" (ibid.: 4). 
the corridor in Dobova. On the other hand, those few refugees who found themselves, for different reasons, on Croatian territory outside the corridor were unable to join the corridor. Since November $3^{\text {rd }}$ and the opening of the camp in Slavonski Brod, in line with the agreement between Croatia and Serbia, the only entry point into the corridor for Croatia was the "border", the train in Šid. ${ }^{4}$

All this suggests the possibility of understanding the corridor from Croatia and onwards as a specific form of detention, mobile detention, which, moreover, was not founded in national or EU legislation, as explained in the case of Slovenia by Neža Kogovšek Šalamon (2016: 44-47). This detention consisted of trains, buses and walking columns of refugees guarded and directed by the police, as well as the camps becoming some form of convergence point for these different pathways of movement. Therefore, it could be said that the corridor was detention in motion with camps as stations.

The corridor as a unique form of detention, as a mobile detention, calls for further research into its mobile aspect. Amongst other things, it calls for research in the vein of viapolitics, a term coined by William Walters (2015a, 2015b: 10) to designate a zone of linked inquiries motivated by the shared conviction that research on migration should be more attentive to the way vehicles and their infrastructures feature in migration controversies, vehicles as mobile zones of governance and contestation in their own right and vehicles as the objects and settings of political action (Walters 2015a: 473-483). Nevertheless, we will not focus here on vehicles, roads or routes, but on the key immobile element of this mobile structure i.e. the camp as an obligatory station of the corridor. In our case, given the fact that we are dealing with the Croatian part of the corridor, this was the camp in Slavonski Brod where we had intermittent, but long term access.

As researchers and volunteers, we first came to the camp in January 2016 and we continuously returned until its closure in mid-April 2016. As we describe elsewhere (Hameršak and Pleše 2017a), ethnographic methods in the camp often boiled down to their bare contours, while our research gained many elements of investigative work. "In an environment where so much was hidden or inaccessible for various reasons, we continually had to discover the basic stratum of the world that we were studying, which the researchers in other contexts generally reach immediately, and without major difficulty" (ibid.: 123). Therefore, in the following pages we focus on the last weeks of the camp and on the confinement of people as probably the most concealed aspect of the camp. Here, we first of all present a basic outline of

Cf. Protokol izmedu Ministarstva unutarnjih poslova Republike Hrvatske, Ravnateljstva policije i Ministarstva unutrašnjih poslova Republike Srbije, Direkcije policije o suradnji u migracijskoj krizi i sprječavanju nezakonitih migracija, October $30^{\text {th }}$ 2015, https://vlada.gov.hr/UserDocsImages// Sjednice/2015/271\%20sjednica\%20Vlade//271\%20-\%2015a.pdf (last access 8 March 2017). 
what was happening in the camp after the overnight closure of the borders (March $8^{\text {th }}$ to March $9^{\text {th }}$ ), and propose a possible framework for understanding it from the perspective of the specific "productiveness" of the camp and modes of resistance to the "rules of camp".

As well as camps in Gevgelija (Macedonia), Preševo (Serbia), Šid (Serbia), Dobova (Slovenia) and elsewhere along the Balkan corridor (cf. Beznec et al. 2016; Kogovšek Šalamon and Bajt 2016; Lunaček Brumen and Meh 2016; Speer 2015), the Slavonski Brod camp was a so-called transit camp. However, it had an exclusively transit function for only a very short period of time. Already on November $18^{\text {th }}$, two weeks after the opening of camp, the refugees who came on the early morning train were no longer without exception directed to one of the sectors from where they were then sent to Slovenia. Instead, on the occasion of this first known example of screening or so-called profiling of refugees in the Slavonski Brod camp, ${ }^{5}$ police directed some of them to the sector on the opposite side of the camp. According

5 The so-called profiling consisted of selection and discrimination control measures used systematically by the police of the countries along the Balkan corridor starting on November $18^{\text {th }}$ 2015, when Slovenia and Croatia extracted the first groups of refugees that did not come from Syria, Iraq or Afghanistan (cf. Inicijativa Dobrodošli, "Nedopustivo je odvajanje izbjeglica na one koje su iz tzv. ratnih zona i na ostale", November 19 $9^{\text {th }} 2015$, http://welcome.cms.hr/index. $\mathrm{php} / \mathrm{hr} / 2015 / 11 / 19 /$ odvajanje-izbjeglica-na-one-koje-su-iz-tzv-ratnih-zona-i-na-ostale/; Moving Europe, "Restrictions and segregation on the Balkanroute: Fences, Detention and Push-Backs", January $21^{\text {th }} 2016$, http://moving-europe.org/restrictions-and-segregation-on-the-balkanroutefences-detention-and-push-backs/\#_ftnref1, last access 8 March 2017). Over the course of time, this profiling led to the mass forced movement of refugees in the opposite direction (people were returned, for example, from Austria to Slovenia, from Slovenia to Croatia, from Croatia to Serbia). People were profiled and returned ("pushed back") on the basis of formal and informal decisions of the states and between the states. Only refugees "coming from Syria, Iraq and Afghanistan could pass along the Balkan route. People of these nationalities also had to, upon entering Slovenia, declare that they intent to go to Austria or Germany if they were to be allowed access to Slovenian territory. By using the method of asking captious questions and, in the case of some countries outsourcing the decision on access to territories to interpreters" (Banich et al. 2016b). On February $18^{\text {th }}$ 2016, the national heads of police in Austria, Slovenia, Croatia, Serbia and Macedonia agreed "that the migration flow along the Western Balkans route has to be reduced to the greatest possible extent". The agreement introduced a unified registration form, as well as defined humanitarian grounds on which "the entry of third country nationals may be authorized" to those who "are arriving from war-torn areas and are in need of international protection (for example from Syria, Iraq)" (https://www.mup.hr/UserDocsImages/topvijesti/2016/veljaca/migranti_sastanak/ joint_statement.pdf, last access 8 March 2017). The result was that Afghans were "being turned away from the Balkan border crossings. Macedonia then closed its borders to Afghan refugees trying to enter from Greece" (Bjelica and van Bijlert 2016). 
to the information available, ${ }^{6} 110$ persons, mostly men from countries such as Lebanon, Pakistan, Nepal, Bangladesh, Morocco, Somalia and Ivory Coast, were separated and directed to this sector. From this time onwards, the Slavonski Brod camp was not only the place where hundreds of thousands of people stopped for a short time in order to proceed further to the West, but also the place where people were forcibly stopped and detained for a shorter or longer period of time, some for a few hours and days and some, in the later period, for weeks or more. From that moment on, their detention took on additional and more easily recognized forms.

The above mentioned first group of people who were separated from the others in the Slavonski Brod camp, could be approached by volunteers on request. In contrast, in the following weeks and months, most of the volunteers were not allowed to approach the detainees as if the detainees had been imprisoned for wrong-doing. In fact, as it has been already noticed, due to the screening or profiling "people who would one day legally enter the countries along the Balkan corridor within the system set up by the authorities of these countries were stopped the next day, their journey interrupted, and they suddenly became illegal and subject to prosecution and detention" (Banich et al. 2016b). Similarly, volunteers were allowed to approach people when they were on their way to Slovenia in "regular transit", but as soon as they were deported from Slovenia to the Slavonski Brod camp, these very same people were labelled as those it was forbidden to approach. Moreover, their detention in the camp was systematically hidden and concealed from the public, as well as from most of the volunteers and employees in the camp. Official reports of the Ministry of Interior Affairs, as well as NGOs, media and other reports did not mention the refugees who were detained in the camp. Therefore, most of the information about imprisonments in the camp came from the outside, as for example from activists of the Moving Europe network. In January 2016, they published a short release about the "systematic violence and unlawful process carried out by Croatian police officers at the Slavonski Brod Transit Camp for Migrants and Refugees" based on insights from the people who were deported to Serbia from the Slavonski Brod camp. ${ }^{7}$ A few weeks later, Moving Europe published a more detailed report about police dealings with so-called non-SIA (Syrian, Iraqi, Afghan) people in the Slavonski Brod camp and at the entry point to the Croatian part of the corridor at the train station in Šid, Serbia (Banich et al. 2016a). Among the published testimonies we also read: "When we arrived to Slavonski Brod the Croatian police told me: 'You are not Iraqi nor Syrian, you can't pass"” (ibid.: 10).

6 Cf. http://welcome.cms.hr/index.php/hr/2015/11/19/odvajanje-izbjeglica-na-one-koje-su-iz-tzvratnih-zona-i-na-ostale/ (last access 8 March 2017).

7 At: http://moving-europe.org/croatia-slavonski-brod-transit-camp-for-migrants-and-refugees/ (last access 8 March 2017). 
People incarcerated in the Slavonski Brod camp arrived there in different ways and from different places. Groups of people or individuals came to the camp by the "regular" refugee trains from Šid or by unmarked police vans, as we had the chance to see ourselves during our stay in the camp. Twice, a train from the West arrived in the camp with a hundred or so people. ${ }^{8}$ Information is even more scarce regarding exits from the camp. The only exception is the mass deportation of 217 refugees to Serbia in February, previously deported from Slovenia to Croatia. ${ }^{9}$ The above mentioned report by Moving Europe refers to a different style of returning refugees to Serbia, in smaller groups and accompanied by violence. According to the testimonies published in the report, police took refugees from the camp to the border zone from where they were forced to walk towards Serbia:

"The next day they told us that we are going to Slovenia now. We had to get into a police car. Then we had to walk 7 kilometers by foot. They told us this is Slovenia, but then it was Serbia. [...] One of my friends tried to run away, but the Croatian police cached [caught] him and beat him here [pointing at his left cheek bone] and here [pointing at his left shoulder]. And at the legs. They were violent and beating him. And when they made us get in to the car they were also using violence. Croatia is no good!" (Banich et al. 2016a: 6)

Finally, one more way to exit the camp for detainees, almost unknown to the public, consisted of the widespread practice of once again joining the refugees, who were previously "pushed back" from Slovenia, to the corridor towards the West. On several occasions in the camp we saw smaller or bigger groups of refugees brought by the police from the dislocated side of the camp to the train platform just before the train's departure.

Regarding the place where people were detained, the only thing that can be said with some certainty is that they were isolated in different parts of the camp, including sectors with containers. In one of the published testimonies we read: "They took me to a room, they kept me there from $12 \mathrm{pm}-20 \mathrm{pm}$. There were around 40 of us kept there" (Banich et al. 2016a: 10). For us on the other side of the fence, the presence of the people detained in the camp was at first made apparent by lights in some of the supposedly empty sectors of the camp. Later on, groups of people of all ages, standing in front of the tent or containers, could sometimes be seen from outside the so-called Sector 3. Since February, more and more people were impris-

8 Cf. http://welcome.cms.hr/index.php/hr/2016/02/17/sigurni-koridor-u-eu-za-neke-koridor-povratka-u-nesigurnost-za-druge/ and http://welcome.cms.hr/index.php/hr/2016/02/28/gradani-europe-porucili-vladama-omogucite-izbjeglicama-siguran-prolaz-sada/ (last access 8 March 2017).

9 Cf. http://welcome.cms.hr/index.php/hr/2016/02/18/europske-zemlje-moraju-solidarno-preuzetiodgovrnost/ and HRT, Dnevnik, February $17^{\text {th }}$ 2016, http://vijesti.hrt.hr/322636/hrvatska-vratila217-izbjeglica-u-sid-slovenija-ima-nove-mjere (last access 8 March 2017). 
oned more frequently and for more substantial periods, among them whole families with children, which was hard to hide as was the case before. Up until the time of writing, it is unknown how many people were detained in the Slavonski Brod camp.

On March $9^{\text {th }}$ after the borders were closed, there were around 300 persons who had been returned to Croatia from Slovenia in the camp. Contrary to media and other accounts (cf. Šelo Šabić and Borić 2016: 12), they did not arrive in the camp after the transit stopped, but they arrived successively in the period between the above mentioned mass deportation to Serbia in mid-February and the closure of the corridor. Ever since the last refugee train departed towards Slovenia, the camp was exclusively a place for detention in the strictest sense, i.e. a place of imprisonment. About two weeks later, two days after the Report on Systemic Human Rights Violations by the Croatian Authorities in the Closed Parts of the Winter Reception and Transit Centre in Slavonski Brod (Banich et al. 2016b) was published, we were allowed to enter the detention sectors for the first time, together with other volunteers and employees present in the camp. ${ }^{10}$

With their "entrance" in the sectors, the process of humanitarisation in the camp started to flourish, which in a way detracted from the fact that individuals of both genders, entire families, teenagers, children, toddlers, new-born, old people, disabled people, people in poor health and others had been forcibly detained. Not only that, the camp in which they were detained was located outside the city and separated from the local surroundings by a high fence and a well-developed security system. The so-called detention sectors of the camp were also separated from each other also by the fence and guarded by the police. These "camps within a camp" consisted of prefabricated plastic or metal constructions placed on gravel pitches. The huge white tent which was used as a dormitory in Sector 1, and the tiny containers which had the same function in Sector 3, were individualized only administratively, with stuck on or handwritten numbers on the "door". In the tents, there were dozens of densely lined bunk beds without mattresses, only with wooden slats. Every occupied slat was, so to speak, the only personal space in the camp. In the tiny containers, the beds filled almost the entire space. That conditions in the camp were truly rudimentary is best seen by the fact that the desire of the volunteers to

10 During the next twenty days or so until the clamp closed, we entered these areas around ten times in total, spending about twenty hours there, which was due to the fact that the organisation we were volunteering for had limited access to them for only a few hours a day, as did most of the others, even after the detention sectors were opened for volunteers and employees of the organisations in the camp. Our ethnographic research in the camp proved to be fraught with methodological dilemmas, problems and obstacles, which we discuss in detail in Hameršak and Pleše 2017a. 
bring in a few mattresses for pregnant and sick women was the subject of constant negotiation, agreements and institutional approval.

Detainees were not allowed to go out of the camp, or even of the sectors. Only exceptionally, some of them were able to get out of the camp with the permission of the police and under their escort if they had to go to the hospital as a patient or "translator" for a friend or family member. As one of our interlocutors reported in his written statement:

"The only kind of freedom we get in this camp[:] get sick and go out. 'Freedom' comes with a price. I really look forward for one of my friend gets sick so that i can go out and for briefest moment be free."

Sometimes a few of them were allowed to go to the grocery store, accompanied by the police officers, to do shopping for themselves and others. Furthermore, they could go out of the sector in which they were being held only in exceptional cases, and also only under police escort. In some cases, their freedom of movement was restricted even within the sectors, for example, at night.

After the borders were closed, people detained in the camp had very limited chances of getting permanent exit out of the camp: seeking asylum in Croatia or voluntarily returning to their home country (excluding Syria) or some other country which would admit them (for example Greece, since those who came through Greece had a six month permit to stay on its territory). Most people opted for the first option hoping to proceed illegally to the West as soon as possible, which in many cases happened soon or immediately after their transfer from the Slavonski Brod camp to Zagreb or Kutina open centres for asylum seekers. Seeking asylum was, namely, a way to exit the camp and gain freedom of movement (cf. Banich et al. 2016b).

As far as we know, a few people left the camp in the way that their relatives came in person to the camp and asked for their release. Locked out of the legal framework, as elaborated in the already mentioned report about the camp (Banich et al. 2016b) they could be released by the very appearance of someone who represented them and their rights. As this example suggests, the Slavonski Brod camp was a place where different standards of justice and law were applied. Moreover, like camps in general, it was a place whose specific "productiveness" consisted "in the very act of decreeing the existence of individuals liable to internment, over and above individual responsibility and biographical factors" (cf. e.g. Rahola 2011: 103). For example, the Slavonski Brod camp defined and redefined identities according to its spatial order. More specifically, in each of the three sectors (so-called Sector 1, Sector 3 and Sector 4) that were in function in the period we are dealing with here, people were held in different sectors according to statuses given to them by the camp administration. In Sector 1, there were men who were identified by the camp administration as single males, regardless of whether they had relatives in the camp or nuclear families, wives 
and children, outside the camp. In Sector 3, there were those who were classified as family members by the camp administration. In Sector 4, there were persons, only men, who were put in additional isolation by the camp administration for a certain period of time. With such spatial grouping, the camp became a place of the production of statuses in its own right. For some, this had radical repercussions at the level of individual biographies as already described in the report on the criminalization and detention of refugees transferred from the camp in Slavonski Brod published after the camp was closed (Inicijativa Dobrodošli 2016).

On April $7^{\text {th }} 2016$ when the closure of the camp was announced, around a hundred people were still in the camp. In the next few days, they were transferred to the centre for asylum seekers in Zagreb or the detention centre in Ježevo, depending on whether or not they had sought asylum, as well as because of the above mentioned statuses and identities acquired during their imprisonment in the camp. All who sought asylum were transferred to the reception and accommodation centre for asylum seekers in Zagreb, and gained freedom of movement on Croatian territory, although within the limits defined by the law and regulations related to asylum seekers. Those who did not seek asylum, but who were placed in Sector 3 and had the status of a family member in the camp, were transferred to the centre for asylum seekers in Zagreb with the argument, as stated in the decisions issued to them, that they had come from war affected areas. On the other hand, those from the Slavonski Brod camp who also did not seek asylum in Croatia, but who were placed in Sector 1 and had the status of "single men" in the camp, were sent to the detention centre in Ježevo where their imprisonment was prolonged (cf. Inicijativa Dobrodošli 2016), although they came from the same war affected countries or areas.

There are numerous and complex reasons, ranging from the very specific to the more general, some of which are already touched upon in the literature (cf. Hess 2012; Papadopoulos et al. 2008: 183-203; Tsianos and Karakayali 2010; Valenta et al. 2015), why refugees detained in the Slavonski Brod camp were delaying seeking asylum. Some of them, as it has been pointed out, refused to seek asylum even when they were faced with having their imprisonment prolonged and being transferred to the Ježevo detention centre. All these reasons connect the constant threat of "virtual prison" (Papadopoulos et al. 2008: 176), fear of being caught in the virtual data networks which increase their deportability (De Genova 2016), and the constant risk of deportation. Seeking asylum in Croatia, which involves registering in the EURODAC (a database of fingerprints of asylum seekers and so-called irregular migrants) will, in line with the Dublin Regulation, further burden their possible future lives in another European country with the constant threat of deportation to Croatia. The Dublin Regulation, according to which the country in which the asylum seeker first applies for asylum is responsible for accepting or rejecting the claim "acts as a hidden hand, forcing asylum seekers to return to countries that have no desire to accommodate them, and in which they have no desire to live" (Migrant 
2017). In case of leaving the country, as harsh statistics (cf. Asylum 2017) and extremely disturbing case studies (cf. Migrant 2017) show, detention and deportation are one of the future scenarios wherever they settle down.

Refusing or delaying to seek asylum in Croatia can be understood also as one of the tactics (de Certeau 1988: 34-39 et passim) to proceed further on one's way to the place, a destination that is not at the moment necessarily conceived as geographic location, but as a good place to live. This refusing or delaying can be understood in terms of waiting. In these circumstances, waiting becomes one of the crucial "survival" tactics, and it is based on know-how of the journey and route to Europe. On this journey, stops are inevitable and they are an integral part of the journey. Although camps "seem to oppose the very core of migration" (Papadopoulos et al. 2008: 191; Tsianos and Karakayali 2010: 381), from one's own and others experiences and knowledge a camp can appear as just another "tolerated station" (Papadopoulos et al. 2008: 191; Tsianos and Karakayali 2010: 381), a place where stopping is only temporary. In this context, rather than being the last stop, the camp, if you wait long enough, can be a ticket to continue the journey (cf. Tsianos and Karakayali 2010: 383). After all, imprisonments in the camps along the Balkan corridor in Slovenia, as well as in the centre in Zagreb, in the detention centre in Postojna or elsewhere were a part of the immediate experience of the refugees arriving at the Slavonski Brod camp. From that perspective, imprisonment in the Slavonski Brod camp could be understood as something one needs to endure to have a chance to proceed to West.

Waiting is an aspect of every bureaucracy, including the one related to the process of seeking asylum, humanitarian stay etc. Concerning this, waiting is not easily recognized as a form of resistance in comparison to other forms of resistance in the Slavonski Brod camp that we know about, such as protesting, sitting-in, demanding, self-harming etc. "Waiting to grab a chance", and even seemingly passive "waiting out" can be seen as a form of "imperceptible politics" of resistance which make up escape (Papadopoulos et al. 2008: 71-82 et passim), i.e. the politics which is "always enacted as ad hoc practices which allow the decomposition of the representational strategies in a particular field and the composition of events which cannot be left unanswered by the existing regime of control" (ibid.: 76). In this context, waiting can be furthermore conceived as a mode of resistance to the bureaucracy and procedures immanent to the camp. Like other invisible, imperceptible daily migrant struggles (e.g. hiding identity, movement, life) by which "status quo is called into question" (Ataç et al. 2015: 7), waiting also more or less successfully, but persistently subverts the migration control regime forcing it to adjust its mechanisms to the autonomy of movement. It is in this vein that the events of the European long summer of migration of 2015 (cf. Kasparek and Speer 2015) can be interpreted, when the closed borders of Europe collapsed under the power of movement which in itself was the accumulation of decades of imperceptible daily struggles and the corridor was made in order to re-establish the control of borders. 


\section{REFERENCES}

Asylum Information Database. 2017. The Dublin System in 2016. Key Figures from Selected European Countries. s. 1.: European Council on Refugees and Exiles. http://s3.amazonaws.com/ecre/wp-content/uploads/2017/03/27170638/ AIDA_2016Update_Dublin.pdf (last access 8 March 2017).

Ataç, Ilker, Stefanie Knron, Sarah Schilliger, Helge Schwiertz and Maurice Stierl. 2015. "Struggles of Migration as In-/Visible Politics. Introduction". movements 1/2: 1-18.

Banich, Selma, Lukas Gerbig and Adrienne Homberger. 2016a. Report on Systemic Police Violence and Push-Backs against Non-SIA People Conducted by Croatian Authorities. http://moving-europe.org/wp-content/uploads/2016/01/28.01.2016_ReportPolice-Violence-and-Push-Backs.pdf (last access 8 March 2017).

Banich, Selma, Sunčica Brnardić, Marijana Hameršak, Sara Kekuš, Iva Marčetić, Mojca Piškor and Magda Sindičić. 2016b. Report on Systemic Human Rights Violations by the Croatian Authorities in the Closed Parts of the Winter Reception and Transit Centre in Slavonski Brod. http://cms.hr/system/article_document/doc/261/Report_on_ Systemic_Human_Rights_Violations_in_the_Winter_Reception_and_Transit_ Centre_in_Slavonski_Brod.pdf (last access 8 March 2017).

Beznec, Barbara, Marc Speer and Marta Stojić Mitrović. 2016. Governing the Balkan Route. Macedonia, Serbia and European Border Regime (Research Paper Series of Rosa Luxemburg Stiftung Southeast Europe 5). Beograd: Rosa Luxemburg Stiftung Southeast Europe.

Bjelica, Jelena and Martine van Bijlert. 2016. "Afghan Exodus. The Opening and Closing of Balkan Corridor". Afghanistan Analysts Network. https://www.afghanistan-analysts.org/afghan-exodus-the-opening-and-closing-of-the-balkan-corridor/?format=pdf (last access 8 March 2017).

de Certeau, Michel. 1998. The Practice of Everyday Life. Berkley, Los Angeles, London: University of California Press. Translated by Steven Rendall.

De Genova, Nicholas. 2002. "Migrant 'Illegality' and Deportability in Everyday Life". Annual Review of Anthropology 31: 419-447.

De Genova, Nicholas, Sandro Mezzadra and John Pickles, eds. 2015. "New Keywords. Migration and Border". Journal of Cultural Studies 29/1: 55-87.

De Genova, Nicholas. 2016. Detention, Deportation, and Waiting. Toward a Theory of Migrant Detainability (Global Detention Project Working Paper 18). https://www. globaldetentionproject.org/wp-content/uploads/2016/12/De-Genova-GDPPaper-2016.pdf (last access 8 March 2017).

Fassin, Didier. 2005. "Compassion and Repression. The Moral Economy of Immigration Policies in France". Cultural Anthropology 20/3: 362-388.

Frontex. 2011. Western Balkans. Annual Risk Analysis 2011. http://frontex.europa.eu/assets/ Attachments_News/wb_ara_2011_for_public_release.pdf (last access 8 March 2017).

Frontex Risk Analysis Unit. 2014. Western Balkans. Annual Risk Analysis 2014. Warsaw: Frontex. http://frontex.europa.eu/assets/Publications/Risk_Analysis/ WB_ARA_2014.pdf (last access 8 March 2017). 
Frontex Risk Analysis Unit. 2016. Western Balkans. Annual Risk Analysis 2016. Warsaw: Frontex. http://frontex.europa.eu/assets/Publications/Risk_Analysis/ WB_ARA_2016.pdf (last access 8 March 2017).

Grubiša, Iva. 2017. “'Us and Them' - Approaching the Refugee Other? Cultural Anthropological Rethinking of the Fieldwork Experience in Slavonia". Narodna umjetnost 54/1: 147-168.

Hameršak, Marijana and Iva Pleše. 2017a. "Winter Reception and Transit Center in the Republic of Croatia. An Ethnographic View of the Slavonski Brod Refugee Camp". Narodna umjetnost 54/1: 101-127.

Hameršak, Marijana and Iva Pleše 2017b. "Zarobljeni u kretanju. O hrvatskoj dionici balkanskog koridora" [Confined in Movement. About the Croatian Section of the Balkan Corridor]. In Kamp, koridor, granica. Studije izbjeglistva u suvremenom hrvatskom kontekstu. Emina Bužinkić and Marijana Hameršak, eds. Zagreb: Institut za etnologiju i folkloristiku, Centar za mirovne studije, Fakultet političkih znanosti Sveučilišta u Zagrebu, Centar za istraživanje etničnosti, državljanstva i migracija, 9-39.

Hart, Laurie Kain. 2011. "Comments. Flow by Stuart Alexander Rockefeller". Current Anthropology 52/4: 571-572.

Hassan, Ali and Linn Biörklund. 2016. "The Journey to Dreamland Never Ends. A Refugee's Journey from Somalia to Sweden”. Refugee Survey Quarterly 35/2: 116136.

Hess, Sabine. 2012. "De-Naturalising Transit Migration. Theory and Methods of an Ethnographic Regime Analysis". Population, Space and Place 18/4: 428-440.

Inicijativa Dobrodošli. 2016. Bez doma i slobode. Izbjeglice u Hrvatskoj - Zidne novine [Without Home and Freedom. Refugees in Croatia - Bulletin Board Newspaper]. $\mathrm{http} / /$ www.cms.hr/system/article_document/doc/282/Zidne_novine_Inicijative_ Dobrodosli.pdf (last access 8 March 2017).

Kasparek, Bernd and Marc Speer. 2015. "Of Hope. Hungary and the Long Summer of Migration”. http://bordermonitoring.eu/ungarn/2015/09/of-hope-en/ (last access 8 March 2017).

Kasparek, Bernd. 2016. "Routes, Corridors, and Spaces of Exception. Governing Migration and Europe". Near Futures Online. Europe at a Crossroads. Managed Inhospitality 1. http://nearfuturesonline.org/wp-content/uploads/2016/01/ Kasparek_Final_PDF.pdf (last access 8 March 2017).

Kogovšek Šalamon, Neža and Veronika Bajt, eds. 2016. Razor-Wired. Reflections on Migration Movements through Slovenia in 2015. Ljubljana: Peace Institute. http:// www.mirovni-institut.si/wp-content/uploads/2016/03/Razor_wired_publikacija_ web.pdf (last access 8 March 2017).

Kogovšek Šalamon, Neža. 2016. "Legal Implications of the 'Humanitarian Corridor". In Razor-Wired. Reflections on Migration Movements through Slovenia in 2015. Neža Kogovšek Šalamon and Veronika Bajt, eds. Ljubljana: Peace Institute, 39-49. http://www.mirovni-institut.si/wp-content/uploads/2016/03/Razor_wired_publikacija_web.pdf (last access 8 March 2017). 
Ladić, Maja and Katarina Vučko. 2016. "Slovenia’s Response to Increased Arrivals of Refugees. We Don't Want Them, but We Don't Also Understand Why They Don't Want to Stay". In Razor-Wired. Reflections on Migration Movements through Slovenia in 2015. Neža Kogovšek Šalamon and Veronika Bajt, eds. Ljubljana: Peace Institute, 15-29. http://www.mirovni-institut.si/wp-content/uploads/2016/03/ Razor_wired_publikacija_web.pdf (last access 8 March 2017).

Lunaček Brumen, Sarah and Ela Meh. 2016. "'Vzpon in padec' koridorja. Nekaj refleksij o spremembah na balkanski migracijski poti od poletja 2015" [The "Rise and Fall" of the Corridor. Some Reflections on the Changes in the Balkans Migration Route after the Summer of 2015]. Casopis za kritiko znanosti 44/264: 21-45.

Migrant Voices. 2017. Road to Nowhere. Case Studies of Europe's Dublin Regulation and Its Imapacts. https://www.scribd.com/document/341947352/Roads-to-Nowhere (last access 8 March 2017).

New Keywords Collective. 2016. "Europe/Crisis. New Keywords of 'the Crisis' in and of 'Europe"'. Near Futures Online. Europe at a Crossroads 1. http://nearfuturesonline. org/wp-content/uploads/2016/01/New-Keywords-Collective_11.pdf (last access 8 March 2017).

Papadopoulos, Dimitris, Niamh Stephenson and Vassilis Tsianos. 2008. Escape Routes. Control and Subversion in 21th Century. London: Pluto.

Petrović, Duško. 2016. Izbjeglištvo u suvremenom svijetu. Od političkoteorijskih utemeljenja do biopolitičkih ishoda [Refugeehood in the Modern World. From Political Theoretical Foundations to Biopolitical Outcomes]. Zagreb: Naklada Ljevak.

Petrović, Duško 2017. "Humanitarno izuzeće. Normalizacija suspenzije prava u kampu i koridoru" [Humanitarian Exemption. Normalization of the Suspension of Rights in Camp and Corridor]. In Kamp, koridor, granica. Studije izbjeglištva u suvremenom hrvatskom kontekstu. Emina Bužinkić and Marijana Hameršak, eds. Zagreb: Institut za etnologiju i folkloristiku, Centar za mirovne studije, Fakultet političkih znanosti Sveučilišta u Zagrebu, Centar za istraživanje etničnosti, državljanstva i migracija, 41-58.

Rahola, Frederico. 2011. "The Detention Machine". In Racial Criminalization of Migrants in 21st Century. Salvatore Palidda, ed. London: Ashgate, 95-106.

Speer, Marc. 2015. "Von Spielfeld nach Slavonski Brod". http://moving-europe.org/vonspielfeld-nach-slavonski-brod/ (last access 8 March 2017).

Stierl, Maurice, Charles Heller and Nicholas De Genova. 2016. "Numbers (or, the Spectacle of Statistics in the Production of 'Crisis')". Near Futures Online. Europe at Crossroads. Managed Inhospitality (Europe/Crisis. New Keywords of "the Crisis" in and of "Europe". Nicholas De Genova and Martina Tazzioli, eds.) 1: 22-25. http://nearfuturesonline.org/wp-content/uploads/2016/01/New-Keywords-Collective_11. pdf (last access 8 March 2017).

Šelo Šabić, Senada and Sonja Borić. 2016. At the Gate of Europe. A Report on Refugees on the Western Balkan Route. Fridrich Erbert Stifung. http://www.irmo.hr/wp-content/ uploads/2016/05/At-the-Gate-of-Europe_WEB.pdf (last access 8 March 2017). 
Škokić, Tea and Renata Jambrešić Kirin. 2017. "The Shopping Center of Abnormal Normality. Ethnography of the Distribution Tent in the Refugee Camp in Slavonski Brod". Narodna umjetnost 54/1: 129-146.

Tsianos, Vassilis and Serhat Karakayali. 2010. "Transnational Migration and the Emergence of the European Border Regime. An Ethnographic Analysis". European Journal of Social Theory 13/3: 373-387.

Valenta, Marko, Drago Zuparic-Iljic and Tea Vidovic. 2015. "The Reluctant AsylumSeekers. Migrants at the Southeastern Frontiers of the European Migration System". Refugee Survey Quarterly 34/3: 95-113.

Walters, William. 2015a. "Reflections on Migration and Governmentality". movements 1/1: 1-25.

Walters, Wiliam. 2015b. "Migration, Vehicles, and Politics. Three Thesis on Viapolitics". European Journal of Social Theory 18/4: 469-488. 